\begin{tabular}{|c|c|c|}
\hline \multicolumn{2}{|c|}{ DJS Vol. 38 (2017) 27-32 } \\
\hline 1969 & $\begin{array}{c}\text { Delta Journal of Science } \\
\text { Available online at } \\
\text { https://djs.journals.ekb.eg/ }\end{array}$ \\
\hline Research Article & MATHEMATICS \\
\hline
\end{tabular}

\title{
The Collapsing of Gas Bubbles in the Bio tissues between Two-Phase Flow and its applications under the effect of Suction Process
}

\author{
S. A.Mohammadein1, A. A. Megahed2 and Asmaa .H. A. Elhabashi1
}

1Department of Mathematics, Faculty of Science, Tanta University, Tanta, Egypt.

2Department of Physics and Mathematics, Faculty of Engineering, Cairo University, Egypt.

Abstract:. The collapse of Nitrogen gas bubbles in the bio tissues of Divers who surface too quickly to the sea level is studied. In this paper, the effects of suction process on the collapsing of gas bubbles with constant ambient obtained. The mathematical model is formulated by Fick, and concentration equations and then solved by analytical method. The collapse of gas bubbles is affected by tissue concentration diffusivity and void fraction. Results showed that, the suction process activates the systemic blood circulation and accelerate the collapsing of gas bubbles in the bio tissues to avoid the incidence of decompression sickness (DCS)

Key words: Decompression sickness (DCS), Biotissues, Nitrogen gas bubble

\section{Introduction}

Decompression sickness (DCS) is a dangerous and occasionally lethal condition caused by nitrogen bubbles that form in the blood and other tissues of divers who surface too quickly or people who flight for long distances from the earth.

Srinvasan et al. [9] have shown that, the threeregion model is suitable for the finite tissue. It is also shown that the two -region model is applicable only to bubble evolution in tissues of infinite extent and cannot be readily applied to bubble evolution in finite tissue volumes to simulate how such evolution is influenced by interaction among multiple bubbles in a given tissue.

Mohammadein and his student [5-7] have solved the problem in unsteady state and concentration distribution around a growing gas bubble is obtained. In the same way, the convective acceleration is added the model [6]. The behavior of bubble growth and distribution is affected by the convection term. In this work we have resolved the problem [7] in case of collapsing bubbles in the bio tissues for Divers under the effect of suction process.

In section 1, the backgrounds of bubble growth are introduced. In sec. 2, the current problem is described by mass, diffusion, Fick equations. The model is solved analytically by the combination of variables to obtain the collapse of gas bubble and concentration distribution surrounding a collapsing gas bubble in the bio tissue. The discussion of results and conclusions are obtained in a third and fourth sections.

The effort is devoted to study the collapse of gas bubbles in the bio tissues of divers under the effect of suction process.

Analysis 
A single gas bubble is considered to collapse inside a tissue between two boundaries $\mathrm{R}_{\mathrm{o}}$ and $\mathrm{R}_{\mathrm{m}}$ as in Fig.1.

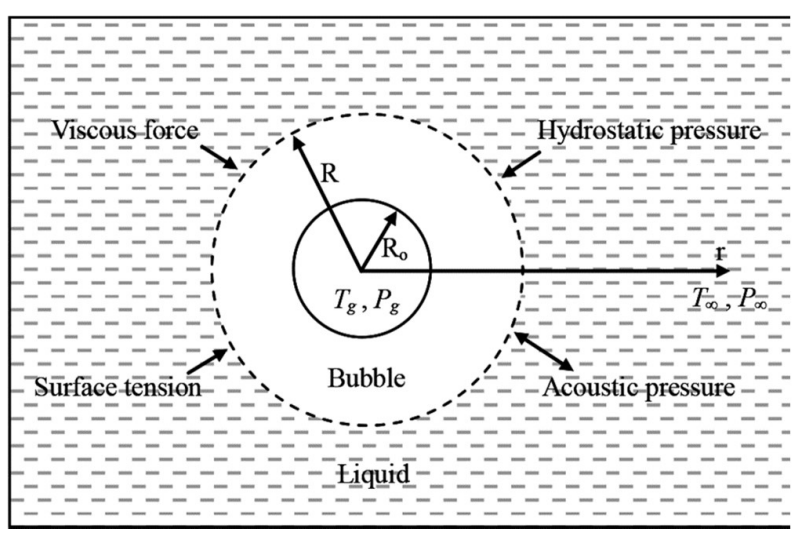

The collapse is affected by some parameters such as the pressure difference between the gas pressure $P_{g}(R(t), t)$ and the ambient pressure $\mathrm{P}_{\mathrm{amb}}(\mathrm{t})$, surface tension of the mixture inside the tissue at the bubble boundary, concentration difference between the two phases and other physical parameters.

The collapse of the gas bubble has been studied based on the following assumptions:

Gases are considered to be ideal.

The bubble is assumed to have a spherical geometry.

Pressure inside the bubble is assumed to be uniform.

Gas density distribution inside the bubble is assumed to be uniform except for a thin boundary layer near the bubble wall.

The viscosity of the fluid is omitted.

Mass balance equation

The mathematical model describing the current problem consists of three equations (mass, diffusion and Fick's equations). The rate of gas uptake by the tissue is the amount carried by the blood per unit time less than the flux into the gas bubble.

$\propto_{\mathrm{T}} \mathrm{V}_{\mathrm{T}} \frac{\mathrm{dP} \mathrm{T}}{\mathrm{dt}}=\mathrm{V}_{\mathrm{T}} \dot{\mathrm{Q}}\left(\mathrm{P}_{\mathrm{a}}-\mathrm{P}_{\mathrm{T}}\right)-\frac{1}{\mathrm{R}_{\mathrm{g}} \mathrm{T}} \frac{\mathrm{d}}{\mathrm{dt}}\left(\mathrm{P}_{\mathrm{g}} \mathrm{V}_{\mathrm{g}}\right)$

\section{Diffusion equation}

Neglecting convection due to bubble movement, the mixture of gas and blood diffusion through the tissue without sources or sinks is described by the flowing equation

$\frac{\partial \mathrm{C}(\mathrm{r}, \mathrm{t})}{\partial \mathrm{t}}=\mathrm{D}_{\mathrm{T}}\left(\frac{\partial^{2} \mathrm{C}}{\partial \mathrm{r}^{2}}+\frac{2}{\mathrm{r}} \frac{\partial \mathrm{C}}{\partial \mathrm{r}}\right)$.

Asuming a spherical symmetry ,the above Eq. (2) with suction process and neglecting convection term is described as follows,

$\frac{\partial \mathrm{c}}{\partial \mathrm{t}}=\mathrm{D}_{\mathrm{T}}\left(\frac{\partial^{2} \mathrm{c}}{\partial \mathrm{r}^{2}}+\frac{2}{\mathrm{r}} \frac{\partial \mathrm{c}}{\partial \mathrm{r}}+\frac{\mathrm{b}}{\mathrm{r}} \frac{\partial \mathrm{c}}{\partial \mathrm{r}}\right)$

Where

$$
\mathrm{b}=-1 \text { suction process. }
$$

Fick's equation

The change of molar concentration of gas in the bubble equals the molar flux of gas through the bubble surface.

Thus, $\quad \frac{1}{\mathrm{Rg}} \frac{\mathrm{d}}{\mathrm{dt}}\left(\frac{4}{3} \pi \mathrm{R}^{3} \mathrm{P}_{\mathrm{g}}\right)=4 \pi \mathrm{R}^{2} \mathrm{D}_{\mathrm{T}}\left(\frac{\partial \mathrm{c}}{\partial \mathrm{r}}\right)_{\mathrm{r}=\mathrm{R}}$.

Pressure balance equation

An effect of pressure at the gas-liquid (blood) interface of the bubble with neglecting tissue viscoelastic becomes.

The relation between gas pressure and ambulant pressure has

the form, in growth stat $\mathrm{P}_{\mathrm{c}}=\mathrm{P}_{\mathrm{amb}}+\frac{2 \sigma}{\mathrm{R}}$

$\mathrm{P}_{\mathrm{g}}=\mathrm{P}_{\mathrm{amb}}-\frac{2 \sigma}{\mathrm{R}}$ 
Analytical solution

For solving the diffusion equation, we use the method of combination variables with assuming that

$$
\begin{aligned}
& C(r, t)=C(s), \\
& s=\frac{\beta r}{f(t)}
\end{aligned}
$$

And at $r=R$, then $s=\beta, R=f(t)$

Based on the above assumptions Eq. (2) introduces the following two equations,

$\mathrm{f}(\mathrm{t}) \dot{\mathrm{f}}(\mathrm{t})=\frac{-\beta^{2} \mathrm{D}_{\mathrm{T}}}{\mathrm{s}}\left(\frac{1}{\mathrm{dc} / \mathrm{ds}} \frac{\mathrm{d}^{2} \mathrm{c}}{\mathrm{ds}^{2}}+\frac{2}{\mathrm{~s}}+\frac{2 \mathrm{~b}}{\mathrm{~s}}\right)=-\mathrm{D}_{\mathrm{T}} \mu$.

And $\dot{\mathrm{ff}}=-\mathrm{D}_{\mathrm{T}} \mu$

We integrate Eq. (8) and by using of the boundary condition at $\mathrm{t}=\mathrm{t}_{\mathrm{o}} \cdot \mathrm{R}=\mathrm{R}_{\mathrm{m}}$. therefore

$R=\sqrt{R_{m}^{2}-2 \mu D_{T}\left(t-t_{0}\right)}$.

Now integrating Eq .(7) twice, then

$\ln \left(\frac{\mathrm{dC}}{\mathrm{dS}}\right)+\ln \left(\frac{\mathrm{A}_{1}}{\mathrm{~S}^{2+\mathrm{b}}}\right)=\frac{\mu \mathrm{S}^{2}}{2 \beta^{2}}$

And as on the form

$\frac{\mathrm{dc}}{\mathrm{ds}}=\frac{\mathrm{A}_{1}}{\mathrm{~S}^{2+\mathrm{b}}} \mathrm{e}^{\left(\frac{\mu \mathrm{s}^{2}}{2 \beta^{2}}\right)}$

On the basis of Fick equation (4), the boundary condition of the bubble becomes,

$\left(\frac{\partial \mathrm{C}}{\partial \mathrm{r}}\right)_{\mathrm{r}=\mathrm{R}}=\frac{1}{3 \mathrm{R}_{\mathrm{g} T \mathrm{~T}_{\mathrm{T}}}}\left(\dot{\mathrm{R}} \mathrm{P}_{\mathrm{amb}}-\frac{4 \sigma}{\mathrm{R}} \mathrm{R}+3 \dot{\mathrm{P}}_{\mathrm{amb}} \dot{\mathrm{R}}\right)$.

But the relation between variables $\mathrm{s}$ and $\mathrm{r}$ becomes,

$\frac{\partial C}{\partial r}=\frac{s}{r} \frac{d c}{d s} \quad$ Then

$$
\left(\frac{\mathrm{dc}}{\mathrm{ds}}\right)_{\mathrm{s}=\beta}=\left(\frac{\mathrm{r}}{\mathrm{s}} \frac{\partial \mathrm{c}}{\partial \mathrm{r}}\right)_{\mathrm{r}=\mathrm{R}, \mathrm{s}=\beta^{\prime}},
$$

$$
\begin{aligned}
& \text { Or } \\
& \left.3 R \dot{R} P_{a m b}-4 \sigma \dot{R}\right)
\end{aligned}
$$

From Eqs.(11) and (13),we get, the constant $A_{1}$ and initial bubble velocity in the form

$$
\begin{aligned}
\mathrm{A}_{1} & =\frac{\beta^{1+\mathrm{b}}\left(\mathrm{R}^{2} \dot{\mathrm{P}}_{\mathrm{amb}}+3 \mathrm{R} \dot{\mathrm{R}} \mathrm{P}_{\mathrm{amb}}-4 \sigma \dot{\mathrm{R}}\right)}{3 \mathrm{R}_{\mathrm{g}} \mathrm{TD}_{\mathrm{T}}} \exp \left(\frac{\mu}{2}\right) \\
\dot{\mathrm{R}}_{\mathrm{o}} & =\frac{\mu \mathrm{D}_{\mathrm{T}}^{2}}{\mathrm{R}_{\mathrm{o}}}
\end{aligned}
$$

Then, $\frac{\partial \mathrm{C}}{\partial \mathrm{r}}=\frac{\mathrm{A}_{1}}{\mathrm{rS}^{\mathrm{b}+1}} \exp \left(\frac{\mu \mathrm{S}^{2}}{2 \beta^{2}}\right)$.

Where $s=\frac{\beta r}{R} \quad$ and $\quad A=\frac{A_{1}}{\beta^{b+1}}$

Integrating the previous equation though the interval from any instant $t$ to $t_{m}$

And maximum bubble radius $\mathrm{R}_{\mathrm{m}}$.at instantt $t_{0}$, and $\mathrm{C}\left(\mathrm{R}_{\mathrm{m}}, \mathrm{t}_{0}\right)=\mathrm{C}_{\mathrm{m}}$, then

$$
\begin{aligned}
& C(r, \\
& A R^{2 b+1} \int_{R_{m}}^{r} \frac{1}{x^{2(b+1)}} \exp \left(\frac{\mu x^{2}}{2 R^{2}}\right) d x .
\end{aligned}
$$

At the bubble wall $r=R(t)$. the previous equation become

$C(R(t), t)-C_{m}=A \int_{R_{m}}^{R(t)} \frac{1}{x^{2(b+1)}} \exp \left(\frac{\mu x^{2}}{2}\right) d x$.

Putting $\mathrm{y}=\frac{\mathrm{x}}{\mathrm{R}}$, thus the previous equation can be written in the form 
$\mathrm{C}(\mathrm{R}(\mathrm{t}), \mathrm{t})-\mathrm{C}_{\mathrm{m}}=\mathrm{k} \int_{\mathrm{R}_{\mathrm{m}} / \mathrm{R}}^{1} \frac{1}{\mathrm{y}^{2(b+1)}} \exp \left(\frac{\mu \mathrm{D}_{\mathrm{T}} \mathrm{y}^{2}}{2}\right) \mathrm{dy}$

Integrating the R. h. s. integral by parts there for equation(18)becomes

$\mathrm{C}(\mathrm{R}(\mathrm{t}), \mathrm{t})-\mathrm{C}_{\mathrm{m}}=\mathrm{k}\left(\frac{\mathrm{r}}{\mathrm{R}}+\frac{\mathrm{D}_{\mathrm{T}} \mu}{6}\left(\frac{\mathrm{r}}{\mathrm{R}}\right)^{3}\right)$

To find the separation constant $\mu$,we assume that $\mathrm{t}=\mathrm{t}_{\mathrm{o}}$ and $\mathrm{R}(\mathrm{t})=\mathrm{R}_{\mathrm{o}}$.

Then Eq.(19) becomes

$\Delta \mathrm{C}_{\mathrm{o}}=\mathrm{C}_{\mathrm{m}}-\mathrm{C}\left(\mathrm{R}_{\mathrm{o}}, \mathrm{t}_{\mathrm{m}}\right)$.

$\Delta \mathrm{C}_{\mathrm{o}}=\frac{-\mathrm{k}}{\mathrm{R}_{\mathrm{o}}^{2}}\left[\left(\mathrm{R}_{\mathrm{o}}-\mathrm{R}_{\mathrm{m}}\right)+\frac{\mu \mathrm{D}_{\mathrm{T}}}{6 \mathrm{R}_{\mathrm{o}}}\left(1-\left(\frac{\mathrm{R}_{\mathrm{m}}}{\mathrm{R}_{\mathrm{o}}}\right)^{3}\right)\right]$

$\varphi_{\mathrm{o}}=\frac{1}{2-\left(\frac{\mathrm{R}_{0}}{\mathrm{R}_{\mathrm{m}}}\right)^{3}}$.

and $\mathrm{k}_{\mathrm{o}}=\left(\frac{\dot{\mathrm{R}}_{\mathrm{o}}{ }^{2} \mathrm{P}_{\mathrm{amb}}+3 \mathrm{R}_{\mathrm{o}} \dot{\mathrm{R}}_{\mathrm{o}} \mathrm{P}_{\mathrm{amb}}-4 \sigma \dot{\mathrm{R}}_{\mathrm{o}}}{3 \mathrm{R}_{\mathrm{g}} \mathrm{TD}_{\mathrm{T}}}\right)$.

The separation constant $\mu$ has the form

$\mu=\left[\frac{8 \Delta \mathrm{C}_{\mathrm{o}}(\mathrm{b}-3)}{\left.\mathrm{A}\left(\frac{\mathrm{R}_{\mathrm{o}}}{\mathrm{R}_{\mathrm{m}}}\right)^{(3-\mathrm{b})}-1\right)}\right]^{\frac{1}{2}}$

From Eqs. (24) and (9), then

$R(t)=\sqrt{R_{m}^{2}-2 \mu D_{T}^{2}\left(t-t_{o}\right)}$.

Discussion of Results

The diffusion equation (2) for a stationary in collapse gas bubble in tissue through decompression in ambient pressure is solved by the method of combination of variables as given relation(9) which represent the solution, describes the collapse of gas bubble in tissue as a function of time
The collapse of gas bubble under the effect of suction process in terms of time for two different values of concentration diffusivity is shown by fig.(2) it observed that the collapse proportion inversely with concentration diffusivity and void fraction in fig.(3)

The collapse of gas bubble in terms of void fraction is shown by fig .(4) it value of void fraction has s observed that the collapse have a constant value then at constant value of void fraction has decreasing

The collapse of gas bubble under the effect of suction process in terms of void fraction with two different values of pressures have decreasing in one value and increasing in another value which shown in fig (5)

The concentration distribution surrounded a collapsing gas bubble in a bio tissue under suction processes is show by fig. (6)

It is observed that, the concentration of blood in bio tissues with solvent nitrogen bubbles increases under the effect of suction process

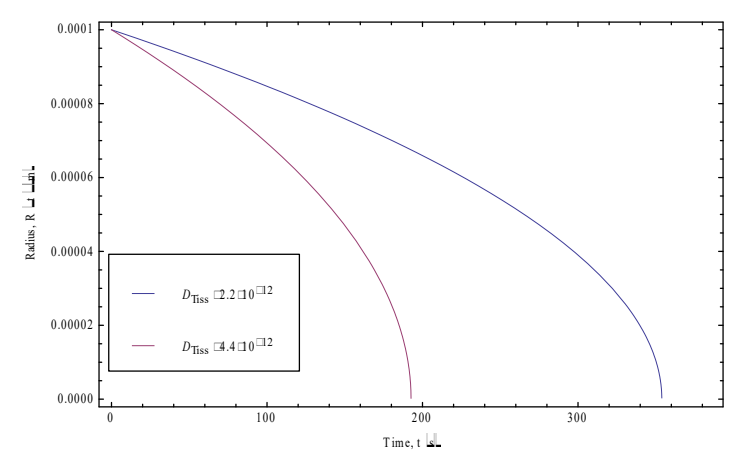

Fig.2.The collapse of gas bubble in terms of time for two different values of concentration diffusivity. 
Fig.3.The collapse of gas bubble in terms of time for two different values of viod fraction.

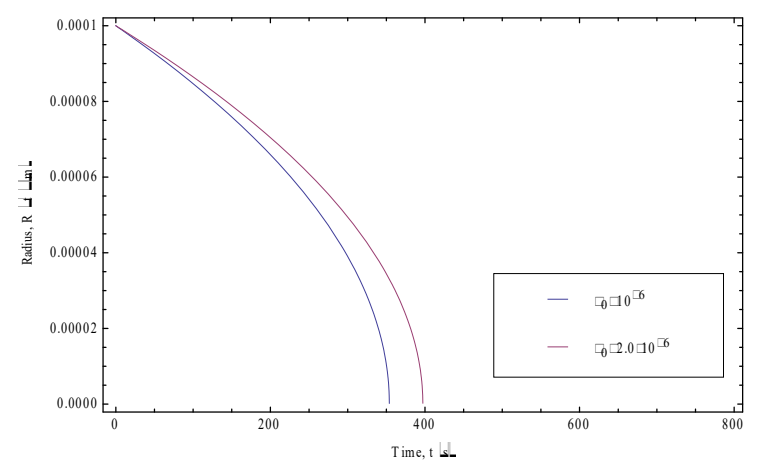

Fig 4.The collapse proportion inversely with viod fraction
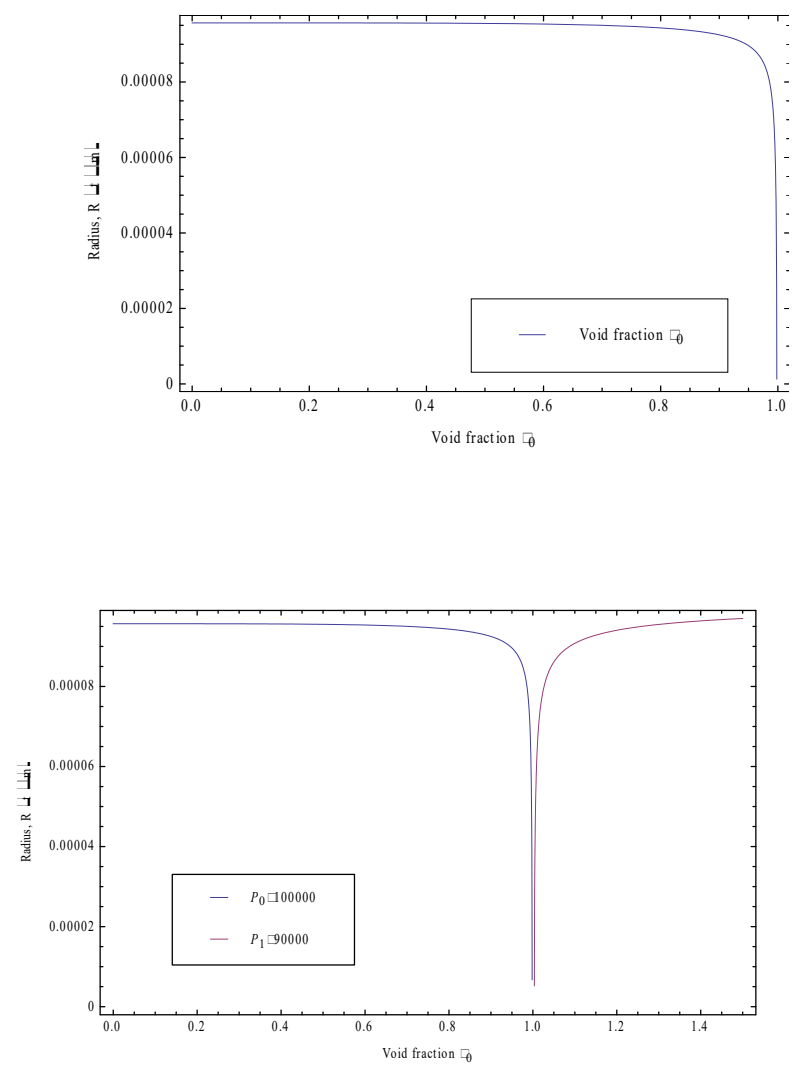

Fig.5.The collapse of gas bubble in terms of void fraction for two different values of pressures

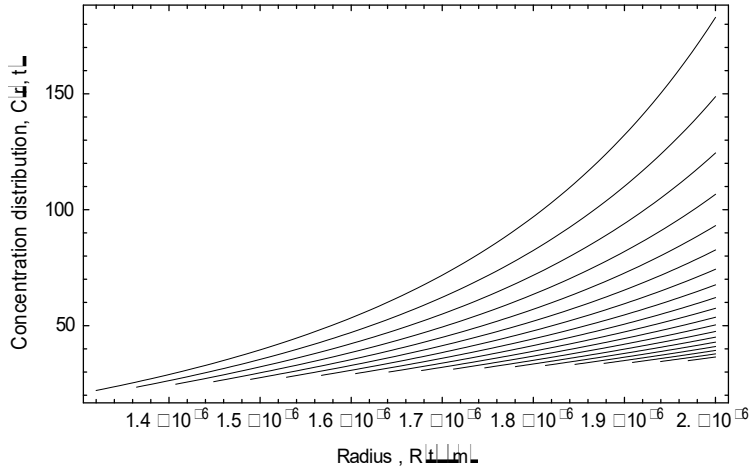

Fig.6.The concentration disctribtion surrounded a collapsing gas bubble in a bio tissue under

\section{Conclusion}

The gas diffusion problem is discussed for unsteady flow in a bio tissue, based on the three region model[2].The concentration around collapsing gas bubble in a bio tissue is obtained analytically for tow main stages as given by Eqs.[21] and[24] respectively. The discussion of results and figures concluded the following remarks

1.The collapse of gas bubble radius is directly proportional to the initial difference of concentration $\Delta \mathrm{C}_{0}$. The diffusivity of the tissue $\mathrm{D}_{\mathrm{T}}$.the initial void fraction $\varphi_{\mathrm{o}}$ and

2.The collapse of gas bubbles is directly proportional to all values of pararmetre " $b "$

3.The effect of suction process $(b=-1)$ on collapse and concentration distribution performs lower values than that obtained by Mohammadein and (zero suction)

4.The effect of suction process on the bio tissues decreases pressure difference in blood circulation of divers when ascending quickly to the surface of sea 
5. The suction process activates the systemic blood circulation and delays the collapse of gas bubbles; which decreasing the incidence of decompression sickness (DCS).

\section{References}

[1] Divinis, N, et al., Bubbles growing in supersaturated solutions at reduced gravity, AIChE J.50 (10)(2004)2369.

[2] Epstein, P. S, and M. S. Plesset. On the stability of gas bubbles in liquid-gas solutions. J. Chem. Phys. 18(1950) 1505.

[3] Hashemi, S. J, and J. Abedi, Advances in modeling of new phase growth. J. Energy Fuels 21(4), (2007).

[4] Lang, M.A, N.E. Smith (Eds),Proceedings Of the Advanced Scientific Diving Workshop,February 23-24,2006,Smithsonian Institution, Washington, DC,2006,277 p.

[5] Mohammadein, S. A, and Mohamed, K. G. Growth of gas bubbles in the bio tissues with Convective acceleration.DOI;10.1142/S1793524514500727.I nt. J. Biomathematics (2014).

[6]Mohammadein, S. A. and Mohamed, K.G. Concentration distribution around a growing gas bubble in tissue. J.Math. Bioscinces.225, 11$7(2010)$
[7] Mohammadein, S. A1.The Concentration distribution around a growing gas bubble in a bio tissue under the effect of suction process. J. Math. Biosciences, Vol. 253 July 2014, pp.88-93

[8] Srinivasan, S. R, W. A. Gerth, and M. R. Powell. Mathematical models of diffusion-limited gas bubble dynamics in tissue,J.Appl.Physiol.86(1999)732

[9] Srinivasan, S. R, W. A. Gerth, and M. R. Powell. A mathematical model of diffusion limited gas bubble dynamics in tissue with varying diffusion region thickness Respir. Physiol. 123(2000).

[10] Tikuisis, P, K. A. Gault, and R.Y.Nishi. Prediction of decompression bubbles and comprtition for gas among bubbles, tissue and blood,J.Appl.Physiol.75(1993)2293.

[11] Wirnke, B. R. Diving decompression models and bubble metrics; modern syntheses,Comput,Bio.Med.39(2009)309.

\footnotetext{
انكماش فقاعه الغاز فى الانسجه الحيويه وتطبيقاتها تحت تأثثير عمليه الثفط

اسماء حبشي احمد الحبثي

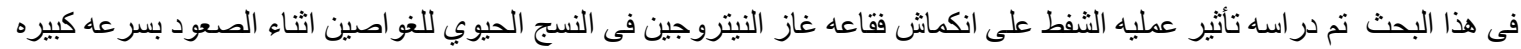

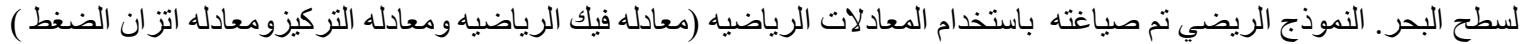

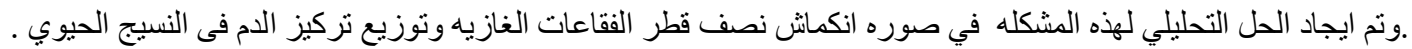

من نتائج البحث ان انكماش فقاعه الغاز يتأثر بتوزيع التركيز فى النسيج الحيوي و عمليه الثفط تؤثر على زياده إنتظام الدوره الدمويه وسر عه

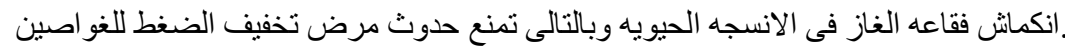

